DOI https://doi.org/10.18551/rjoas.2017-02.13

\title{
INSTITUTIONAL PERFORMANCE ANALYSIS OF UPPB ON RUBBER TRADE SYSTEM IN SOUTH SUMATRA, INDONESIA
}

\author{
Novayanti* \\ Agricultural and Food Security Agency, Palembang, Indonesia \\ Sriati, Yamin, Amruzi Minha \\ ${ }^{2}$ Faculty of Agriculture, University of Sriwijaya, Indonesia \\ *E-mail: novayantikushartoyo@yahoo.com
}

\begin{abstract}
A study of the institutional performance of Natural Rubber Processing and Marketing Unit (Unit Pengolahan dan Pemasaran Bokar or UPPB) on rubber trade system in South Sumatra. The purpose of this study is to analyze the institutional performance of UPPB on rubber business administration in South Sumatra. The institutional performance of UPPB on rubber marketing in South Sumatra is influenced by the characteristics of its farmers, institution, institution leadership, values, and local government (autonomy implementation). While on the other hand, the physical and social environment of the farmers, institution leadership, and social institution do not affect the institutional performance of UPPB. In addition to that, the institutional performance of UPPB has certainly affected the welfare of the farmers. If the institutional performance is increasing, the welfare of the farmers will be improved too (vice versa).
\end{abstract}

\section{KEY WORDS}

UPPB, institutional performance, trade system, rubber marketing.

Indonesia is one of the countries which has a fairly extensive rubber plantation. Based on the data from Indonesian Plantation Research Center, an approximately $85,17 \%$ of about 3,5 million hectares' area of rubber plantation is the people's plantation in which it involves $2,093,803$ farmers. Another thing about this fact is that the area of people's rubber plantation has increased by $1,78 \%$ in the last 10 years.

Based on a review of Bank Indonesia (The Indonesian Bank), not only as a source of foreign exchange revenue, rubber industry is also a source of employment in which $53,4 \%$ of South Sumatra's population work in the agriculture sector, especially the rubber business. However, the contribution of rubber in the economy tends to be down as a result of a decreased rubber commodity export due to a lower commodity price. Of the average total rubber export in Sumatra per year, the value of the loss has reached between the price of $\$ 364,78$ per year. This was caused by the rubber price in Indonesia that was happened to be the lowest compared to other countries because of its low quality. With the decreased rubber commodity export and price, this made farmers' welfare to be dropped in which it was reflected in the fall of NTP (Nilai Tukar Petani or Farmers' Exchange Rate).

Historically, in the natural rubber trade system, an institutional system that regulates the interaction between actors in natural rubber marketing system has been formed naturally. Rubber farmers sell their product to the peasants who are generally own a convenience store or smokehouse. The relationship between peasants with farmers is formed in an institution in the form of agreement (rules) that regulates not only limited to the transactions of natural rubber but also in terms of farmers' basic needs. Based on the author's observation, the trade system of natural rubber in South Sumatra shows a very complex structure and directed to oligopsonistic market.

In the regulation of the Minister of Agriculture number 38 article 16 of 2008, it is stated that in term of natural rubber processing and marketing activities, the farmers are being grouped in UPPB (Natural Rubber Processing and Marketing Unit or Unit Pengolahan dan 
Pemasaran Bokar); there are 8 regencies/cities in South Sumatra which have UPPB. The total UPPB in South Sumatra is as much as 72 UPPB, however, there are only 7 regencies/cities in South Sumatra which have a registered UPPB (precisely, there are 71 registered UPPB). In correlation with that, this study aims to analyze the institutional performance of UPPB on natural rubber business administration in South Sumatra.

\section{LITERATURE REVIEW}

The term institutional includes two important demarcation, such as (1) norms and conventions, and (2) rules of the game. Sometimes, an institutional is formally written and enforced by government officials, but it also can be written informally due to the rules and norms which are adopted by society. So, an institution can be defined as collective activities in a control or jurisdiction, deliverance or liberation, and expansion of individual activities as mentioned above (Arifin, 2005).

Seen from the formation process, there are two forms of institutions, namely an institution which grows naturally and an institution which is constituted deliberately based on the purpose of development (Saptana, 2006). While according to Anindita (2004), an institutional trading system covers a wide range of business organization which is build to run a marketing system.

The Regulation of the Minister of Agriculture number 38/The Regulation of the Minister of Agriculture/OT.140/2008 regarding Guidelines for Natural Rubber Processing and Marketing is stipulated by the Minister of Agriculture on August 12, 2008, in which it consisted of 6 chapters and 39 articles. The scope of this regulation covers; Processing, Institutional, Marketing, Development, and Supervision. By that, in order to improve the economy scale in processing and marketing the enterprises, an institution of Natural Rubber Processing and Marketing Unit (UPPB) is established.

The performance or outcome in an institutional system is the result of a complex process that is influenced by various factors. (Ostrom, 2006).

\section{RESEARCH METHODOLOGY}

This study was conducted from September until December 2016 in South Sumatra Province as one of the largest rubber producers in Indonesia. The 7 districts/cities which were chosen to be the focus of this research were Ogan Ilir (OI), Muara Enim, Prabumulih, Ogan Komering llir (OKI), Ogan Komering Ulu, Ogan Komering Ulu Timur (OKUT), and Banyuasin. Those areas became the focus of this research not only by the fact that these 7 districts/cities were the center of rubber producers in South Sumatra but also that they had the institutional form of the rubber trade system in the registered UPPB and other agencies such as cooperatives and farmers'group. The selection of the seven locations was done intentionally (purposive) because each district/city has an institutional form of rubber trade system with the above provisions.

Furthermore, survey method and literature will be used as an object of study. In this study, survey method was limited by observing the phenomenon with the survey sample, data, and information from a group of respondents as a representative embodiment of the study object.

Moreover, the data used in this study were primary data and secondary data. Primary data was taken from respondents through interviews by using a structured questionnaire and in-depth interviews with several selected respondents. The source of primary data was not only from the employee of the registered UPPB and other institutions such as cooperatives and farmers' group but also from the rubber farmers in the local area of Ogan llir (OI), Muara Enim, Prabumulih, Ogan Komering Ilir (OKI), Ogan Komering Ulu, Ogan Komering Ulu Timur (OKUT), and Banyuasin. Meanwhile, the secondary data was obtained from various sources such as annual reports of district/city evaluation and relevant research literature.

The samples or subsets of this research were the institution of rubber trade system and farmers' in rubber production center districts/cities that have the registered UPPB and other 
institutions such as cooperatives and farmers' group. In this study, there would be an assessment of the phenomenon of institutional performance on rubber trade system in South Sumatra and also an evaluation of the dimensions and interrelations by using SEM (Structural Equation Model) technique.

Based on the population distribution in each layer, the percentage that was used in the sampling was adapted to the number of the population so that it would be a representative of scientific principles. In all layers of samples, only $30 \%$ of the sample would be taken due to the fact that the population was $<1000$. The sampling of this study was carried out with probability, which was a stratified random sampling. On the other hand, the amount of the samples which was taken in each stratum was based on a proportionate stratified random sampling. From 7 population, there would be 4 targeted population; the population was then divided into 2 strata based on the existence of registered UPPB and other institutions, namely:

The data processing and analysis which require the help of statistical tools was carried out by using descriptive statistics and inferential statistics. Besides that, the value of $t_{\text {count }}$ compared with the value of $t_{\text {table }}$ was used to know the difference between the mean of each variable in the 2 groups of samples. This means if $t_{\text {arithmetic }} \leq t_{t a b l e}$, then, there was a difference in between the mean. Meanwhile, when $t_{\text {count }}>t_{\text {table, }}$, then, there would be no difference between the mean of the samples that was tested at a significance level of $p<0.05(\alpha=0.95)$ or $p<0.01(\alpha=0.99)$.

\section{RESULTS AND DISCUSSION}

Table 1 - The Best Output Outer Model, AVE and Composite Reliability

Outer Loadings

\begin{tabular}{|c|c|c|c|c|}
\hline & $\mathbf{X 1}$ & $\mathbf{X 2}$ & $\mathbf{X 3}$ & $\mathbf{X 4}$ \\
\hline $\mathbf{X 1 1 0}$ & 0.800968 & & & \\
\hline $\mathbf{X 1 3}$ & 0.845960 & & & \\
\hline $\mathbf{X 2 3}$ & & 1.000000 & & \\
\hline $\mathbf{X 3 3}$ & & & 0.560991 & \\
\hline $\mathbf{X 3 6}$ & & & 0.863683 & \\
\hline $\mathbf{X 4 2}$ & & & & 0.996880 \\
\hline $\mathbf{X 4 3}$ & & & & 0.639998 \\
\hline & $\mathbf{X 5}$ & $\mathbf{X 6}$ & $\mathbf{X 7}$ & $\mathbf{Y 1}$ \\
\hline $\mathbf{X 5 1}$ & 1.000000 & & & \\
\hline $\mathbf{X 6 1}$ & & 0.920491 & & \\
\hline $\mathbf{X 6 2}$ & & 0.766646 & & \\
\hline $\mathbf{X 7 2}$ & & & 1.000000 & \\
\hline $\mathbf{Y 1 1 0}$ & & & & 0.790442 \\
\hline $\mathbf{Y 1 1 1}$ & & & & 0.524613 \\
\hline $\mathbf{Y 1 2}$ & & & & 0.529105 \\
\hline $\mathbf{Y 1 4}$ & & & & 0.774777 \\
\hline $\mathbf{Y 1 5}$ & & & & 0.617680 \\
\hline $\mathbf{Y 1 6}$ & & & & \\
\hline $\mathbf{Y 1 8}$ & & & & \\
\hline
\end{tabular}

AVE

\begin{tabular}{|c|c|}
\hline & AVE \\
\hline X1 & 0.678599 \\
\hline X2 & 1.000000 \\
\hline X3 & 0.530330 \\
\hline X4 & 0.701684 \\
\hline X5 & 1.000000 \\
\hline X6 & 0.717525 \\
\hline X7 & 1.000000 \\
\hline Y1 & 0.448007 \\
\hline
\end{tabular}

Composite Reliability

\begin{tabular}{|c|c|}
\hline & $\begin{array}{c}\text { Composite } \\
\text { Reliability }\end{array}$ \\
\hline $\mathbf{X 1}$ & 0.808415 \\
\hline $\mathbf{X 2}$ & 1.000000 \\
\hline $\mathbf{X 3}$ & 0.683621 \\
\hline $\mathbf{X 4}$ & 0.817878 \\
\hline $\mathbf{X 5}$ & 1.000000 \\
\hline $\mathbf{X 6}$ & 0.834393 \\
\hline $\mathbf{X 7}$ & 1.000000 \\
\hline Y1 & 0.847420 \\
\hline
\end{tabular}

From the table above, the evaluation of outer model includes:

The value of outer loading is a measurement model coefficient which measures the construct validity of the PLS model. The value of this outer loading is considered valid when it is $>0,5$. From the results of the output, as we can see above, all outer loading values are valid. 
Average variance extracted (AVE) is the average of the outer loading variance which quantifies the construct validity of the PLS model. The value of AVE shows a valid (accurate) model when it is $>0,5$. So, from the table, there is 1 invalid AVE which is the Y1 construct.

The value of composite reliability $(C R)$ is a coefficient that determines a construct reliability of the PLS model. CR value is seen as a reliable (trustworthy) model when the CR is $>0,7$. By that, we can conclude that $1 \mathrm{CR}$ is not reliable (X3 construct). Due to the good values of outer loading, the value of AVE in Y1 construct and CR in X3 construct can be tolerated in order to protect the indicator of $Y 111, Y 12$, and $X 33$ which are already valid.

Table 2 - Output Inner Model: R Square and Path Coefficients

R Square

\begin{tabular}{|l|l|}
\hline & R Square \\
\hline X1 & \\
\hline X2 & \\
\hline X3 & \\
\hline X4 & \\
\hline X5 & \\
\hline X6 & \\
\hline X7 & \\
\hline Y1 & 0.478040 \\
\hline
\end{tabular}

Path Coefficients

\begin{tabular}{|c|c|c|c|c|}
\hline & $\mathbf{X 5}$ & $\mathbf{X 6}$ & $\mathbf{X 7}$ & $\mathbf{Y 1}$ \\
\hline $\mathbf{X 1}$ & & & & 0.204898 \\
\hline $\mathbf{X 2}$ & & & & 0.069346 \\
\hline $\mathbf{X 3}$ & & & & 0.226750 \\
\hline $\mathbf{X 5}$ & & & & 0.286699 \\
\hline $\mathbf{X 6}$ & & & & 0.125333 \\
\hline $\mathbf{X 7}$ & & & & 0.360715 \\
\hline $\mathbf{Y 1}$ & & & & 0.023142 \\
\hline
\end{tabular}

Significance test (t-test) for Path Coefficients is not succeeded, so, the bootstrapping method is given with this following results:

Table 3 - Output Inner Model with Bootstrapping: Path Coefficients (Mean, STDEV and T-Values)

Path Coefficients (Mean, STDEV, T-Values)

\begin{tabular}{|l|c|c|c|c|}
\hline & $\begin{array}{c}\text { Original Sample } \\
(\mathbf{0})\end{array}$ & Sample Mean (M) & $\begin{array}{c}\text { Standard } \\
\text { Deviation } \\
\text { (STDEV) }\end{array}$ & $\begin{array}{c}\text { Standard Error } \\
\text { (STERR) }\end{array}$ \\
\hline $\mathbf{X 1 ~}>\mathbf{Y 1}$ & 0.204898 & 0.205236 & 0.080941 & 0.080941 \\
\hline $\mathbf{X 2} \rightarrow \mathbf{Y 1}$ & 0.069346 & 0.074293 & 0.104666 & 0.104666 \\
\hline $\mathbf{X 3} \rightarrow \mathbf{Y 1}$ & 0.226750 & 0.217844 & 0.102080 & 0.102080 \\
\hline $\mathbf{X 4} \rightarrow \mathbf{Y 1}$ & 0.286699 & 0.278687 & 0.107539 & 0.107539 \\
\hline $\mathbf{X 5} \rightarrow \mathbf{Y 1}$ & 0.125333 & 0.117334 & 0.085001 & 0.085001 \\
\hline $\mathbf{X 6} \rightarrow \mathbf{Y 1}$ & 0.360715 & 0.379582 & 0.133378 & 0.133378 \\
\hline $\mathbf{X 7} \rightarrow \mathbf{Y 1}$ & 0.023142 & 0.020385 & 0.111595 & 0.111595 \\
\hline
\end{tabular}

\begin{tabular}{|l|c|}
\hline & $\begin{array}{c}\text { T Statistics } \\
(\mid \text { O/STERR } \mid)\end{array}$ \\
\hline $\mathbf{X 1} \rightarrow \mathbf{Y 1}$ & 2.531450 \\
\hline $\mathbf{X} 2 \rightarrow \mathbf{Y 1}$ & 0.662548 \\
\hline $\mathbf{X 3} \rightarrow \mathbf{Y 1}$ & 2.221307 \\
\hline $\mathbf{X} 4 \rightarrow \mathbf{Y 1}$ & 2.665997 \\
\hline $\mathbf{X 5} \rightarrow \mathbf{Y 1}$ & 1.474477 \\
\hline $\mathbf{X 6} \rightarrow \mathbf{Y 1}$ & 2.704457 \\
\hline $\mathbf{X 7} \rightarrow \mathbf{Y 1}$ & 0.207375 \\
\hline
\end{tabular}

Outer evaluation model (measurement model), includes:

The value of outer loading is a coefficient which measures the construct validity of the PLS model. The value of this outer loading is considered valid when it is $>0,5$. So, from the results, the values of valid outer loading are given in Table 4.

Average variance extracted (AVE) is the average of the outer loading variance which quantifies the construct validity of the PLS model. The value of AVE shows a valid (accurate) model when it is $>0,5$. From the results of the output, all AVE values are valid.

The value of composite reliability $(C R)$ is a coefficient that determines a construct reliability of the PLS model. CR value can be said as a reliable (trustworthy) model when the $\mathrm{CR}$ is $>0,7$. As we can see from the output, all CR are reliable. Then, here is the summary of AVE and CR (Table 5).

The evaluation of inner model (structural model) is the path coefficients which measure the influence of the constructs. In order to test the path coefficients with t-test, the following hypothesis is given:

a. $H_{0}$ : No partial effect $(X 1, X 2, X 3, X 4, X 5, X 6$, and $X 7$ to $Y 1)$.

b. $H_{1}$ : No partial effect $(X 1, X 2, X 3, X 4, X 5, X 6$, and $X 7$ to $Y 1)$. 
Table 4 - The value of outer loading with SEM-PLS UPPB

\begin{tabular}{|c|c|c|}
\hline Construct & Indicator & Loading \\
\hline \multirow{2}{*}{ X1 } & $\mathrm{X} 110$ & 0,800968 \\
\hline & $\mathrm{X} 13$ & 0,845960 \\
\hline $\mathrm{X} 2$ & $\mathrm{X} 23$ & 1,000000 \\
\hline \multirow[b]{2}{*}{ X3 } & X33 & 0,560991 \\
\hline & X36 & 0,863683 \\
\hline \multirow{2}{*}{$\mathrm{X} 4$} & $\mathrm{X} 42$ & 0,996880 \\
\hline & $\mathrm{X} 43$ & 0,639998 \\
\hline $\mathrm{X} 5$ & $\mathrm{X} 51$ & 1,000000 \\
\hline \multirow[b]{2}{*}{$\mathrm{X} 6$} & $\mathrm{X} 61$ & 0,920491 \\
\hline & X62 & 0,766646 \\
\hline $\mathrm{X} 7$ & $\mathrm{X} 72$ & 1,000000 \\
\hline \multirow{7}{*}{ Y1 } & Y111 & 0,790442 \\
\hline & Y110 & 0,524613 \\
\hline & Y12 & 0,529105 \\
\hline & Y14 & 0,695794 \\
\hline & Y15 & 0,774771 \\
\hline & Y16 & 0,700107 \\
\hline & Y18 & 0,617680 \\
\hline
\end{tabular}

Table 5 - The value of AVE and CR with SEM-PLS UPPB

\begin{tabular}{|c|c|c|}
\hline Construct & AVE & CR \\
\hline $\mathrm{X} 1$ & 0,678599 & 0,808415 \\
\hline $\mathrm{X} 2$ & 1,000000 & 1,000000 \\
\hline $\mathrm{X} 4$ & 0,530330 & 0,683621 \\
\hline $\mathrm{X} 5$ & 0,701684 & 0,817878 \\
\hline $\mathrm{X} 6$ & 1,000000 & 1,000000 \\
\hline $\mathrm{X} 7$ & 0,717525 & 0,834393 \\
\hline $\mathrm{Y} 1$ & 1,000000 & 1,000000 \\
\hline & 0,448007 & 0,847420 \\
\hline
\end{tabular}

In this t-test, the value of path coefficients is said to be statistically significant if the value of $\mid t$-value $\mid \geq t_{\alpha / 2 v}$. From here, a calculation of $\alpha / 2=0,05 / 2=0,025$ dan $v=n-p=144$ $-(18+7)=199$ is generated, so that the value of $t_{\text {table }}$ or $t_{\alpha / 2 v}=t_{0,025,119}=1,9719$ (approach value on $v=200)$.

\section{CONCLUSION}

The institutional performance of UPPB on natural rubber trade system in South Sumatra is influenced by the characteristics of the farmers, institution, institution leadership, values, and local government (autonomy implementation). While on the other hand, the physical and social environment of the farmers, institution leadership, and social institution do not have any effect on the institutional performance of UPPB.

Besides that, the institutional performance of UPPB could affect the welfare of the farmers. When institutional performance is increased, the welfare of the farmers will also be enhanced, vice versa.

\section{REFERENCES}

1. Arifin, Z. (2005). Teori Keuangan dan Pasar Modal. Ekonisia. Yogyakarta.

2. Anindita, R. (2004. Pemasaran Hasil Pertanian. Papyrus, Surabaya.

3. Saptana. 2006. Analisis Kelembagaan dan Kemitraan Usaha di sentra Produksi sayuran. Pusat Penelitian dan Pengembangan Sosial Ekonomi Pertanian.

4. Ostrom, E. and Nagendra, H. 2006. Understanding Institutional Diversity. Princenton University Press. USA.

5. Peraturan Menteri Pertanian No.38/Permentan/OT.140/8/2008 tentang Pedoman Pengolahan dan Pemasaran Bahan Olah Karet. 